\title{
Faktor Risiko Non Viral Pada Karsinoma Nasofaring
}

Sukri Rahman, Bestari Jaka Budiman, Histawara Subroto,

\begin{abstract}
Abstrak
Latar belakang: Karsinoma nasofaring adalah tumor ganas epitel nasofaring yang sampai saat ini penyebabnya belum diketahui, infeksi virus Epstein Barr dilaporkan sebagai faktor dominan terjadinya karsinoma nasofaring tetapi faktor non viral juga berperan untuk timbulnya keganasan nasofaring. Tujuan: Untuk mengetahui faktor non viral yang dapat meningkatkan kejadian karsinoma nasofaring sehingga dapat mencegah dan menghindari faktor-faktor non viral tersebut. Tinjauan Pustaka: Karsinoma nasofaring merupakan tumor ganas epitel nasofaring yang penyebabnya berhubungan dengan faktor viral dan non viral diantaranya asap rokok, ikan asin, formaldehid, genetik, asap kayu bakar, debu kayu, infeksi kronik telinga hidung tenggorok, alkohol dan obat tradisional. Kesimpulan: Pembuktian secara klinis dan ilmiah terhadap faktor non viral sebagai penyebab timbulnya karsinoma nasofaring masih belum dapat dijelaskan secara pasti. Faktor non viral merupakan salah satu faktor risiko yang dapat meningkatkan angka kejadian timbulnya keganasan nasofaring
\end{abstract}

Kata kunci: karsinoma nasofaring, faktor risiko, non viral

\begin{abstract}
Background: Nasopharyngeal carcinoma is a malignant epithelial nasopharyngeal tumor that until now the cause still unknown, Epstein barr virus infection had reported as predominant occurance of nasopharyngeal carcinoma but non viral factors may also contribute to the onset of the incidence of nasopharyngeal malignancy. Purpose: To find non viral factors that may increase the incidence of nasopharyngel carcinoma in order to prevent and avoid non-viral factors Literature: Nasopharyngeal carcinoma is a malignant tumor that causes nasopharyngeal epithelium associated with viral and non-viral factors such as cigarette smoke, salt fish, formaldehyde, genetic, wood smoke ,wood dust, ear nose throat chronic infections, alcohol, and traditional medicine. Conclusion: Clinically and scientifically proving the non-viral factors as the cause of nasopharyngeal carcinoma can not be explained with certainty. Non-viral factors only as one risk factor that can increase the incidence of the onset of nasopharyngeal carcinoma.
\end{abstract}

Keywords: nasopharyngeal carcinoma, risk factor, non viral

Affiliasi penulis : Sukri Rahman

Korespondensi : [sukri_rahman@yahoo.com] Bagian Telinga Hidung Tenggorok Bedah Kepala dan Leher (THT-KL) Fakultas Kedokteran Universitas Andalas, Padang Telp: 0751

\section{Pendahuluan}

Karsinoma nasofaring (KNF) adalah tumor ganas epitel nasofaringyang merupakan suatu tumor ganas utama di nasofaring pada daerah endemis. Karsinoma nasofaring adalah tipe tumor dengan distribusi endemis yang unik. ${ }^{1}$ Karsinoma nasofaring ini dapat ditemukan diseluruh negara dari lima benua tetapi insiden tertinggi terdapat di Cina bagian selatan khususnya di provinsi Guangdong dan jarang ditemukan di Eropa dan Amerika Utara. ${ }^{2}$ Insiden di provinsi Guangdong pada pria mencapai 20 50/100000. ${ }^{1} \quad$ Insiden kejadian kanker nasofaring dihubungkan dengan faktor geografi dan latar belakang etnik.

Karsinoma nasofaring (KNF) adalah penyakit keganasan tersering di Cina bagian selatan serta Asia Tenggara dan bersifat multifaktorial diantaranya faktor genetik, virus dan lingkungan (Gambar 1). ${ }^{3,4,5,6}$

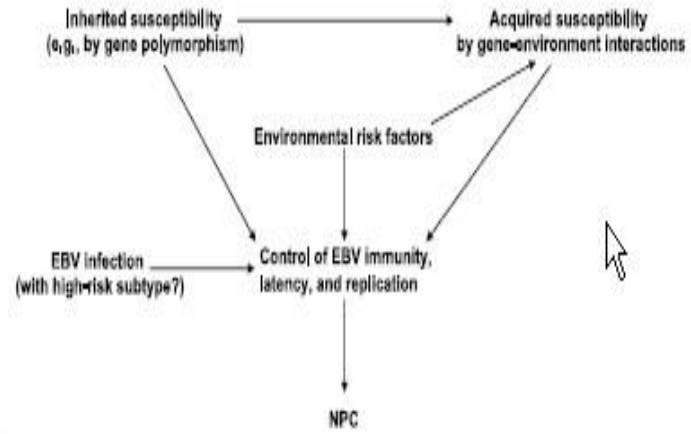

Gambar 1. Skema hubungan antara virus Epstein Barr, genetik dan lingkungan.

Dari sejumlah literatur disebutkan bahwa infeksi virus Epstein Barr merupakan etiologi yang paling dominan untuk timbulnya karsinoma nasofaring. Faktor non viral dianggap sebagai salah satu faktor risiko yang dapat meningkatkan angka kejadian timbulnya keganasan nasofaring. Lebih dari $90 \%$ seluruh penduduk dunia telah terinfeksi virus Epstein Barr, tetapi infeksi primer virus Epstein Barr ini masih inaktif dan belum 
menunjukkan gejala klinis. ${ }^{6}$ Hubungan karsinoma nasofaring (KNF) dengan virus Epstein Barr ditemukan pada tahun 1966 berdasarkan hasil penelitian secara serologi yaitu ditemukannya EBV DNA dan EBV nuclear antigen (EBNA) pada penderita KNF. ${ }^{7}$ Pajanan faktor non viral seperti lingkungan dan genetik dapat mengaktivasi virus Epstein Barr inaktif menjadi aktif sehingga akan menimbulkan gejala klinis karsinoma nasofaring. ${ }^{6}$ Beberapa penelitian melaporkan bahwa penyebab non viral kanker nasofaring diantaranya konsumsi ikan asin, makanan yang diawetkan, asap rokok, asap kayu bakar, obat nyamuk bakar dan infeksi kronik saluran nafas bagian atas berulang. . $^{3,4}$

Insiden kanker nasofaring pada laki-laki sekiar 2-3 kali lebih tinggi dibandingkan dengan wanita. insiden kanker nasofaring mulai meningkat setelah usia 30 tahun, 93\% terjadi setelah melewati usia 30 tahun dengan puncak tertinggi saat usia 45-55 tahun.

\section{Anatomi}

Karsinoma nasofaring (KNF) adalah suatu karsinoma sel skuamosa (KSS) yang berasal dari sel epitel nasofaring. Keganasan ini dapat muncul dari berbagai tempat di nasofaring, tetapi lebih sering terdapat pada fossa Rosenmuller, yaitu ressesus yang terletak di medial dari krura medial tuba eustachius. ${ }^{8}$

Struktur anatomi nasofaring pada etnis Cina dan Asia umumnya sempit dibandingkan dengan etnis berkulit putih sehingga mudah terjadinya deposit aerosol serta iritasi secara langsung yang menyebabkan infeksi berulang seperti faringitis kronik yang menyebabkan mukosa nasofaring dalam periode waktu tertentu mengalami perubahan kearah keganasan. ${ }^{9}$

\section{Histopatologi}

WHO tahun 1992 mengklasifikasikan karsinoma nasofaring ke dalam 3 tipe secara histologis : Squamous sel karsinoma dengan keratin (WHO tipe 1); Squamous sel karsinoma non keratin berdiferensiasi (WHO tipe 2); Squamous sel karsinoma non keratin tidak berdiferensiasi (WHO tipe 3). ${ }^{3,8,10}$ Untuk WHO tipe 1 banyak ditemukan di Amerika Utara sedangkan di Cina Selatan hanya sekitar $2 \%$, untuk WHO tipe 2 sekitar $12 \%$ ditemukan di Amerika Utara sedangkan di Cina Selatan hanya $3 \%$ dan WHO tipe 3 merupakan tipe paling banyak ditemukan di Cina Selatan yaitu mencapai $95 \%{ }^{7}$

Sel epitel pada KNF adalah sel poligonal

yang berukuran besar, nukleusnya berbentuk bundar atau oval dengan kromatin yang jarang dan nukleoli yang jelas. Sel-selnya seringkali dikacaukan oleh sel-sel limfoid pada nasofaring, yang menimbulkan istilah limfoepithelioma. ${ }^{8}$ Tipe histologis dari KNF dibedakan ke dalam 2 kelompok: yakni karsinoma sel skuamosa berkeratin dan karsinoma tidak berkeratin selanjutnya tipe yang kedua dibedakan menjadi karsinoma terdiferensiasi dan tidak terdiferensiasi. Klasifikasi baru ini menunjukkan suatu prognosis, dimana karsinoma yang tidak terdiferensiasi memiliki tingkat kontrol tumor lokal yang lebih tinggi dengan radioterapi. ${ }^{8}$

\section{Etiologi}

Etiologi karsinoma nasofaring bersifat multifaktorial. faktor infeksi virus Epstein Barr sangat dominan untuk terjadinya karsinoma nasofaring tetapi faktor non viral seperti konsumsi ikan asin, kebiasaan merokok, pengawet makanan, asap kayu bakar, obat nyamuk bakar, infeksi saluran pernafasan atas berulang dan genetik dilaporkan berhubungan dengan kejadian karsinoma nasofaring. . $^{3,11}$

Penyebab kanker nasofaring sangat unik dan sulit untuk dijelaskan. Antibodi terhadap virus Epstein Barr ditemukan pada serum pasien kanker nasofaring ( Old et al.1996) dan pada beberapa penelitian ditemukan peningkatan yang sangat signifikan dari kadar antibodi Epstein Barr antibodi. ${ }^{10}$ Perbedaan ras, etnik, geografi, lingkungan dan genetik berkontribusi untuk timbulnya karsinoma nasofaring. Pada beberapa literatur dikatakan juga bahwa konsumsi makanan dengan bahan pengawet, asap rokok, ikan asin, riwayat infeksi saluran nafas atas berulang, menghirup asap obat nyamuk bakar dan asap kayu bakar dapat meningkatkan kejadian kanker nasofaring. ${ }^{3}$

\section{Faktor Non Viral Pada Karsinoma Nasofaring}

\section{Asap Rokok}

Pada banyak penelitian dikatakan bahwa merokok berhubungan dengan terjadinya keganasan ini. Merokok dapat meningkatkan serum anti-EBV. ${ }^{11}$ Serum anti-EBV merupakan marker yang digunakan untuk menilai adanya proses keganasan pada nasofaring, anti-EBV ini terbagi dua yaitu serum antiEBV viral capsid antigen immunoglobulin $A$ dan anti$E B V$ DNase. ${ }^{3,9}$ Peningkatan marker anti-EBV positif dapat dimiliki pada orang-orang yang memiliki kebiasaan merokok aktif selama lebih dari 20 tahun. ${ }^{11}$

Pada penelitian di Amerika bahwa dua pertiga kanker nasofaring WHO tipe 1 disebabkan oleh asap rokok tetapi kanker nasofaring WHO tipe 2 dan 3 tidak berhubungan dengan asap rokok. ${ }^{3}$ Asap rokok mengandung sekitar 4000 senyawa kimia dan lebih dari 60 senyawa kimia tersebut bersifat karsinogen. ${ }^{4,11}$

Beberapa penelitian melaporkan bahwa pada perokok berat insiden kanker nasofaring meningkat 2-4 kali lebih tinggi dibandingkan yang bukan perokok. ${ }^{6}$ Perokok aktif dengan konsumsi kumulatif rokok lebih dari 30 bungkus dalam setahun dapat meningkatkan kejadian karsinoma nasofaring dibandingkan dengan perokok aktif yang menghabiskan kurang dari 30 bungkus dalam setahun. ${ }^{11,12}$ 


\section{Ikan Asin}

Konsumsi ikan asin merupakan salah satu penyebab karsinoma nasofaring yang sering dilaporkan, mungkin ini berkaitan dengan substansi karsinogen yang terdapat didalamnya yaitu nitrosamin. ${ }^{8}$ Nitrosamin adalah suatu molekul yang terdiri dari nitrogen dan oksigen, molekul tersebut dapat berbentuk senyawa nitrit dan NOx yang terdiri dari senyawa amino dan senyawa campuran nitroso. ${ }^{13}$

Sumber utama nitrosamine dapat berasal dari eksogen maupun endogen, nitrosamin endogen berasal dari sintesis didalam lambung dari prekursor yang berasal dari makanan yang dicerna, sedangkan nitrosamin eksogen berasal dari makanan, rokok, emisi industri dan bahan kosmetik yang mengandung nitrosamin itu sendiri. Nitrosamin dapat berbagai bentuk senyawa kimia diantaranya $N$ nitrosodimethylamine (NDMA), N-nitrosodiethylamine (NDEA), N-nitromorpholine (NMOR), selain itu nitrosamine dapat juga berupa senyawa industri seperti $\quad \mathrm{N}$-nitrosodiisopropylamine (NDiPA), $\quad \mathrm{N}$ nitrosodibutylamine (NDPA), N-nitrosopiperidine (NPip), $\quad N$-nitrosopyrrolidine (NPyr), $N$-nitrosomethylphenylamine NEPhA). Sekitar $80 \%$ dari total nitrosamin terbanyak dalam bentuk senyawa nitrosodimethylamine (NDMA). NDMA terutama diabsorpsi di saluran pernafasan, saluran pencernaan dan terkadang pada kulit. Proses keganasan dapat terjadi akibat metabolisme nitrosamine yang diaktivasi oleh mekanisme oksidasi sehingga terjadi mutasi DNA. Konsentrasi total N-nitrosodimethylamine (NDMA) pada kandungan nitrosamine yaitu 0,74$11,43 \mu \mathrm{g} / \mathrm{m}^{3}$, berdasarkan penelitian dan sejumlah literature bahwa ambang dasar paparan nitrosamine pada manusia antara $2,5 \mu \mathrm{g} / \mathrm{m}^{3}-15 \mu \mathrm{g} / \mathrm{m}^{3}$ selama periode waktu 10 tahun berhubungan dengan kejadian keganasan. ${ }^{13}$

Dalam uji kasus kontrol menunjukkan bahwa hanya konsumsi ikan asin yang berlebihan sebelum usia 10 tahun berhubungan dengan peningkatan risiko berkembangnya karsinoma nasofaring. ${ }^{14}$ Pada ikan asin selain mengandung nitrosamin juga mengandung bakteri mutagen dan komponen yang dapat mengaktivasi virus Epstein Barr. ${ }^{11}$ Konsumsi ikan asin yang terus menerus dalam jangka waktu yang lama dapat meningkatkan angka kejadian karsinoma nasofaring. Di Cina bagian selatan ikan asin merupakan makanan awal yang sering diberikan orang tua kepada bayi dan anak-anak karena status sosial ekonomi rendah. Akumulasi bahan kimia nitrosamin dan prekursor nitrosamine telah dilaporkan sebagai bahan karsinogenik pada binatang.,4,5

Makanan yang diawetkan dengan diasinkan juga dapat meningkatkan risiko terjadinya kanker nasofaring seperti sayuran yang diasinkan, udang asin, telur asin serta makanan lain yang diasinkan. ${ }^{14}$ Konsumsi teh dan buah-buahan segar dapat menurunkan angka kejadian kanker nasofaring karena mengandung zat antioksidan dan zat antikanker yang dapat merubah struktur kimia nitrosamin. ${ }^{5}$ Buah segar yang mengandung banyak vitamin $\mathrm{C}$ dapat menghambat formasi nitrosamine dengan inhibisi proses mutagenesis dan karsinogenesis serta inhibisi pertumbuhan sel tumor dan kerusakan sel DNA. Beberapa penelitian di Cina menemukan beberapa tumbuhan herbal dapat bersifat antikanker dengan cara mengaktifasi proses apoptosis dan differensiasi sel dengan meningkatkan sistem imun dan menghambat proses angiogenesis. ${ }^{14}$

\section{Formaldehid}

Formaldehid adalah suatu senyawa karsinogenik yang dapat menyebabkan proses keganasan pada rongga hidung. Metaanalisis yang dilakukan lebih dari 30 tahun menunjukkan bahwa paparan formaldehid berhubungan dengan kejadian karsinoma nasofaring. Pada tahun 1995, International Agency for Research on Cancer (IARC) memasukkan formaldehid kedalam salah satu penyebab karsinoma nasofaring. ${ }^{1,15,16,17}$ Kemudian Pada tahun 2004 International Agency for Research on Cancer ( IARC) memberikan kategori grup I pada formaldehid sebagai bahan yang bersifat karsinogen dalam tubuh manusia. IARCH mengevaluasi pajanan formaldehid sebagai penyebab kematian akibat kanker nasofaring. ${ }^{16,18}$

Formaldehid merupakan produk senyawa alami yang dihasilkan dari lingkungan dan digunakan dalam kehidupan sehari-hari. Formaldehid banyak digunakan sebagai senyawa pelarut, larutan desinfektan dan pengawet. ${ }^{19}$ Gas formaldehid $(\mathrm{CH} 2 \mathrm{O})$ merupakan senyawa yang mudah terbakar, tidak berwarna dan banyak juga digunakan dalam pembuatan resin, pelapis kayu, foto film dan pengawet jaringan. Formaldehid dapat mengiritasi mata dan mukosa saluran pernafasan atas dengan konsentrasi 0,5-1 ppm. ${ }^{15}$ Menurut Occupational Safety and Health Administration (OSHA) bahwa standar pajanan maksimal formaldehid yaitu 2 ppm dalam STEL (Short Term Exposure Limit) dan standart pajanan maksimal 0,75 ppm dalam waktu 8 jam TWA ( Time Weight Average). ${ }^{16}$ Gas formaldehid dapat menyebabkan kanker pada rongga hidung, nasofaring, laring, mulut dan kelenjar ludah. ${ }^{17}$ Pada penelitian para pekerja dibidang patologi, anatomi, kremasi mayat dan pekerja lain yang terpapar formaldehid dikatakan bahwa zat formaldehid dapat meningkatkan risiko terkenanya kanker otak, leukemia, kanker rongga hidung dan sinus paranasal serta kanker nasofaring. ${ }^{15,16,19}$

\section{Genetik}

Faktor genetik berperanan penting sebagai etiologi karsinoma nasofaring. Riwayat keluarga dengan salah satu anggota keluarga penderita karsinoma nasofaring meningkatkan kemungkinan salah satu anggota keluarga mendapatkan keganasan nasofaring. Dilaporkan pada banyak literatur bahwa Human leucocyt antigen (HLA) kemungkinan berhubungan dengan peningkatan kejadian karsinoma nasofaring, di Tunisia tipe HLA yang berhubungan 
dengan timbulnya karsinoma nasofaring adalah HLAB13, di Algeria dinamakan HLA-A3,B5 dan B15, di Maroko HLA-B18 sedangkan HLA-Aw33,B14 dan A9 tidak berhubungan sebagai faktor timbulnya karsinoma nasofaring. ${ }^{20}$ Di benua Asia termasuk Cina, HLA ini dinamakan sesuai rantai alelnya yaitu HLA-A2 dan B46. Kehilangan alel pada kromosom 3,4,9,11 dan 14 dapat meningkatkan kejadian karsinoma nasofaring. ${ }^{3}$

Pada literatur lain disebutkan kelainan genetik pada metabolisme enzim seperti kelainan enzim sitokrom P450 2E1 (CYP2E1) ,sitokrom P450 2A6 (CYP2A6) dan tidak adanya enzim glutathione S-transferase M1 (GSTM1) serta GSTT1 berkontribusi untuk terjadinya karsinoma nasofaring. ${ }^{3,21}$ Adanya reseptor immunoglobulin PIGR ( Polymeric Immunoglobulin Receptor) pada sel epitel nasofaring dapat meningkatkan kejadian karsinoma nasofaring. PIGR merupakan reseptor permukaan pada sel epitel nasofaring yang berfungsi menghantarkan masuknya Epstein Barr Virus kedalam epitel nasofaring sehingga dapat meningkatkan kejadian karsinoma nasofaring. ${ }^{3}$

Ada penelitian yang menyebutkan adanya hubungan golongan darah tipe A dengan peningkatan kejadian karsinoma nasofaring dan golongan darah tipe $\mathrm{O}$ mempunyai efek proteksi terhadap kejadian karsinoma nasofaring. Hal ini belum bisa dijelaskan secara pasti karena sejumlah penelitian lain menyebutkan tidak adanya hubungan antara tipe golongan darah dengan karsinoma nasofaring. ${ }^{5}$

\section{Asap Kayu Bakar dan Debu kayu}

Risiko terjadinya kanker nasofaring meningkat terhadap paparan debu kayu yang terakumulasi dalam jangka waktu lama. Debu kayu menyebabkan iritasi dan inflamasi pada epitel nasofaring sehingga mengurangi bersihan mukosiliar dan perubahan sel epitel di nasofaring. ${ }^{3}$ Partikel debu berukuran sedang ( 5-10 $\mu \mathrm{m}$ ) mudah diserap di daerah faring. Beberapa penelitian epidemiologi menemukan bahwa faktor risiko timbulnya karsinoma nasofaring meningkat pada orang-orang yang terpapar dengan debu kayu dan semua hal tersebut tergantung dari lama dan dosis paparan. Selain itu salah satu faktor risiko lainnya adalah orang-orang yang bekerja pada suhu tinggi dan lingkungan kerja yang mudah terbakar. ${ }^{1,17}$ Nasofaring merupakan daerah utama terperangkapnya partikel berukuran menengah ( 5-10 $\mu \mathrm{m})$ dari partikel-partikel inhalasi sehingga memudahkan penyerapan zat kimia kedalam epitel nasofaring dan zat inhalasi ini bersifat karsinogen sebagai faktor risiko timbulnya karsinoma nasofaring. ${ }^{17}$ Paparan asap kayu hasil dari pembakaran kayu bakar untuk memasak selama lebih dari 10 tahun dapat meningkatkan kejadian kanker nasofaring sekitar 6 kali lipat. ${ }^{6}$

\section{Infeksi Kronik Telinga-Hidung-Tenggorok}

Pada beberapa penelitian mengungkapkan bahwa infeksi kronik berulang pada telinga-hidung- tenggorok serta saluran nafas bagian bawah meningkatkan 2 kali lipat kejadian karsinoma nasofaring. Beberapa bakteri dapat merubah Nitrat menjadi Nitrit sehingga menghasilkan struktur kimia yang bersifat karsinogenik yaitu campuran $\mathrm{N}$-Nitroso. ${ }^{3}$ Bahan-bahan kimia yang bersifat karsinogenik seperti deposit aerosol pada nasofaring menyebabkan perubahan struktur sel didaerah tersebut. $^{9}$

Perubahan jaringan epitel nasofaring akibat proses inflamasi dari bakteri, virus atau parasit dapat menstimulasi Nitric Oxide (NO). Senyawa Nitric Oxide (NO) adalah senyawa yang dihasilkan dari perangsangan Nitric Oxide Synthase (iNOS) akibat proses inflamasi dari epitel nasofaring. iNOS dapat mengkatalisasi oksidasi dari $\quad L$-arginine menjadi L-citruline, NO dan Reactive Nitrogen Species (RNS) yaitu NOx dan peroxynitrite. RNS dapat merubah formasi DNA menjadi 8-NitroG (8-nitroguanine) melalui proses nitrasi. 8-nitroG adalah suatu lesi nitrasi DNA yang berpotensial sebagai DNA mutagen penyebab karsinogenesis sedangkan 8-OHdG ( 8hydoxy-2-deoxyguanosine) adalah DNA mutagen yang berasal dari proses oksidasi peroxynitrite dari C8 di rantai guanin melalui proses oksidasi. Guanin (G) dinitrasi menjadi 8-Nitroguanine (8-NitroG) nitratif pada karbon kedelapan. Deoxyguanosine (dG) dioksidasi menjadi 8-Hydroxyguanosine pada karbon kedelapan. $^{2}$ ( Gambar 2 )

(8-OHdG) oksidatif
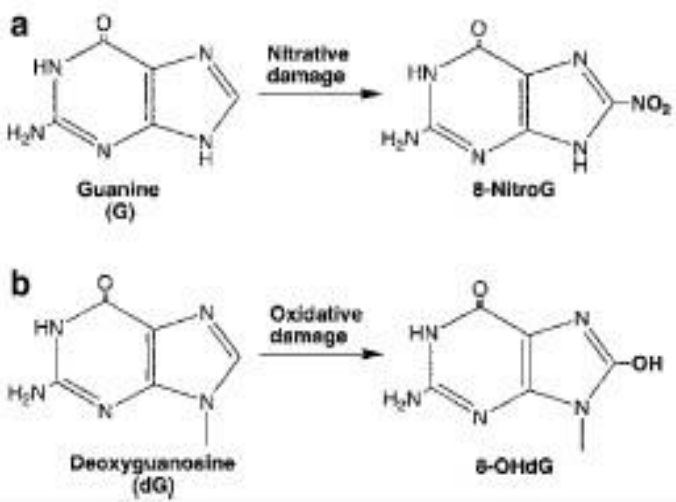

Gambar 2. Pembentukan reaksi dan konformasi dari 8-nitroguanine (8-NitroG) dan 8-hydroxyguanine (8$\mathrm{OHdG}){ }^{2}$

Nitric Oxide (NO) dipercayai sebagai senyawa yang dapat mengakibatkan kerusakan sel DNA melalui perubahan struktur kimia dari 8nitroguanine (8-NitroG) dan 8-hydroxyguanine (8$\mathrm{OHdG}$ ) yang memicu timbulnya keganasan nasofaring, kedua struktur kimia tersebut dihasilkan dari proses nitrasi dan oksidasi dari Nitric Oxide (NO) dan dapat digunakan sebagai biomarker pada penelitian karsinoma nasofaring. ${ }^{2}$

Sel epitel nasofaring patologis dirangsang oleh proses peradangan yang menyebabkan akumulasi makrofag, sel endotel, dan neutrofil dalam jaringan nasofaring sehingga iNOS terus mengalami overexpress. Kemudian iNOS menginduksi dan mensintesis NO dan bersama Reactive Oxygen 
Species (ROS) kemudian merusak jaringan DNA Hal ini dapat meningkatkan pertumbuhan dan metastasis $\mathrm{KNF}^{2}{ }^{2}$ ( Gambar 3 )

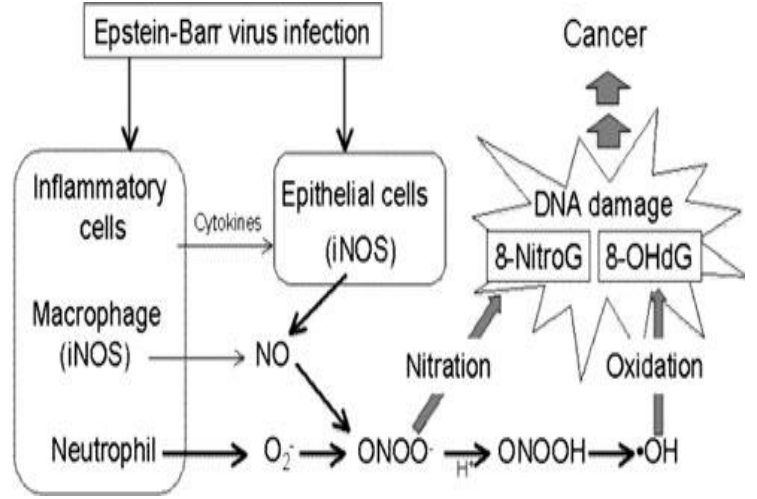

Gambar 3. Skema Perkembangan KNF yang berhubungan dengan kerusakan DNA oksidatif melalui iNOS menjadi 8-NitroG dan 8-OHdG. ${ }^{2}$

Pememeriksaan biomarker 8-NitroG dan 8-OHdG ini dapat dilakukan dengan cara pewarnaan double immunofluorescent pada sediaan biopsi jaringan nasofaring. Pada teknik ini juga dapat dilakukan pemeriksaan ekspresi iNOS pada sediaan biopsi jaringan nasofaring. Selain itu kadar serum $8-\mathrm{OHdG}$ juga dapat diperiksa dengan menggunakan Enzym Linked Immunosorbent Assay (ELISA). ${ }^{2}$ Proses inflamasi dan infeksi merupakan kejadian yang tersering pada saluran pernafasan atas, proses hiperplasia ringan dapat terjadi pada daerah epitel normal nasofaring sehingga hiperplasia ringan tersebut berubah menjadi lesi displasia berat atau karsinoma in situ (CIS). ${ }^{7}$

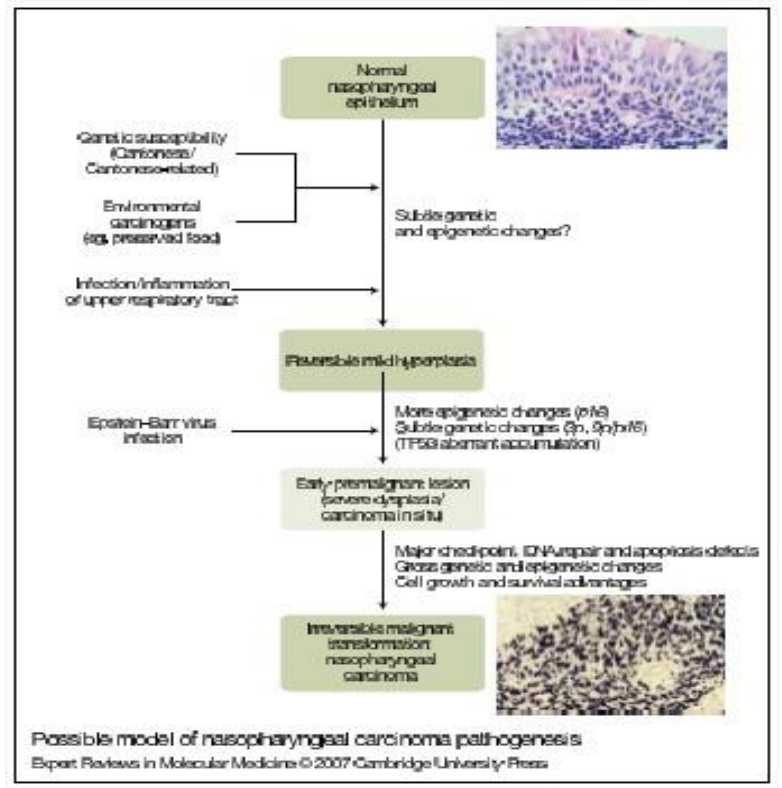

Gambar 4. Patogenesis karsinoma nasofaring

\section{Alkohol}

Pada sejumlah penelitian, peran konsumsi alkohol sebagai salah satu faktor terjadinya karsinoma nasofaring masih dipertanyakan, meskipun ada kemungkinan konsumsi alkohol tidak berkontribusi terjadinya karsinoma nasofaring. Pada beberapa penelitian menyebutkan adanya hubungan antara alkohol dan karsinoma nasofaring berdasarkan lokasi geografi, metode pengukuran kadar alkohol serta faktor lain sebagai penyebab karsinoma nasofaring. Penggunaan alkohol dengan kadar yang tinggi dapat menjadi faktor risiko timbulnya karsinoma sel skuamosa dengan tipe yang tidak berdifferensiasi dan karsinoma sel skuamosa yang tidak berkeratin. Ethanol merupakan komponen yang menjadi penyebab perkembangan kanker sedangkan asetaldehid adalah produk oksidasi dari alkohol yang dapat bersifat toksik, karsinogenik dan mutagenik. Konsumsi alkohol yang tinggi dapat menyebabkan induksi enzim sitokrom P 450 yang akan menyebabkan kerusakan sel. Alkohol juga dapat menyebabkan defisiensi vitamin dan mineral seperti asam folat, zinc, besi dan vitamin A sehingga menyebabkan regulasi dan diffrensiasi sel. ${ }^{22}$

\section{Obat Tradisional}

Pada sejumlah penelitian yang dilakukan di Asia tenggara dan Cina Selatan bahwa penggunaan obat tradisional berhubungan dengan meningkatnya kejadian karsinoma nasofaring hingga 2-4 kali. ${ }^{14}$ Beberapa tumbuhan sebagai bahan dasar dari obat dapat menginduksi virus Epstein Barr dalam fase laten. Komposisi Tetradecanoylphorbol Acetate (TPA) yang ada didalam tumbuhan jika di kombinasikan dengan senyawa $N$-butyrate yaitu senyawa yang diproduksi oleh bakteri yang berada di faring dapat menginduksi sintesis virus Epstein Barr dan meningkatkan transformasi sel B lalu terbentuk suatu genesis karsinoma nasofaring. ${ }^{1}$

Obat herbal merupakan bagian dari pengobatan yang ada di negara Cina dan dibeberapa negara, meskipun beberapa penelitian menyebutkan bahwa obat herbal dapat meningkatkan kejadian karsinoma nasofaring, tetapi di Cina Selatan tidak ada penelitian yang menerangkan adanya hubungan antara tumbuhan herbal dengan peningkatan karsinoma nasofaring setelah meneliti setiap tumbuhan yang digunakan sebagai obat herbal di Cina, adapun yang menarik pada penelitian di Cina menyebutkan bahwa kebiasaan orang Cina minum teh herbal, buah-buahan dan sup sayuran dapat menurunkan kejadian karsinoma nasofaring. Tumbuhan herbal dapat berperan sebagai antikanker melalui peningkatan sistem imun tubuh dengan cara menginduksi proses apoptosis. ${ }^{14}$

\section{Kesimpulan}

Etiologi karsinoma nasofaring sampai saat ini belum diketahui secara jelas. Pembuktian secara klinis dan ilmiah terhadap faktor non viral sebagai penyebab timbulnya karsinoma nasofaring masih belum dapat dijelaskan secara pasti. Faktor-faktor non viral sebagai faktor risiko timbulnya karsinoma nasofaring saling berkaitan. Hal ini memerlukan penelitian yang lebih 
lanjut dan terfokus mengenai faktor lingkungan dan genetik sebagai faktor risiko terjadinya karsinoma nasofaring.

Etiologi pasti karsinoma nasofaring (KNF) sampai saat ini belum diketahui tetapi sejumlah literatur mengemukakan bahwa etiologi terbanyak karsinoma nasofaring adalah virus Epstein Barr yaitu sekitar $90-95 \%$ selebihnya sekitar $5-10 \%$ disebabkan oleh faktor non viral. Faktor non viral berperanan penting dalam reaktivasi virus Eptein Barr sebagai pemicu timbulnya keganasan nasofaring, hal ini telah dibuktikan dari sejumlah penelitian yang mengungkapkan bahwa genetik dan lingkungan merupakan prekursor aktivasi virus Epstein Barr.

\section{Daftar Pustaka}

1. Ma J, Cao S. The Epidemiology of Nasopharyngeal Carcinoma. In. Lu J.J, Cooper J.S , Lee A.W.M, editors. Nasopharyngeal Carcinoma. Berlin Heidelberg; 2010. P 1-7

2. Huang $Y Z$, Zhang BB, Ma N, Murata M, Tang A, Huang GW. Nitrative and Oxidative DNA Damage as Potential Survival Biomarkers for Nasopharyngeal Carcinoma. Med Oncology 2011;28:377-84

3. Chang ET, Adami HO. The Enigmatic Epidemiology of Nasopharyngeal Carcinoma. Cancer Epidemiologic Biomarkers Prev 2006;15(10):1765-77

4. Ekburaranawat W, Ekspanyaskul C, Brennan P, Kanka C, Tepsuwan K, Temisyatith $S$ et al. Evaluation of Non-Viral Risk Factors for Nasopharyngeal Carcinoma in Thailand: results from a Case-control Study. Asian Pacific J Cancer Prev 2010;11:929-32

5. Turkoz FP, Celenkoglu G, Dogu GG, Kalender ME, Coskun U, Alkis $\mathrm{N}$ et al. Risk Factors of Nasopharyngeal Carcinoma in Turkey- an Epidemiological Survey of the Anatolian Society of Medical Oncology. Asian Pacific J Cancer Prevention 2011;12:3017-21

6. Guo X, Johnson RC, Deng H, Liao J, Guan L, Nelson GW, Tang M et al. Evaluation of Nonviral Risk Factors for Nasopharyngeal Carcinoma in a High-Risk Population of Southern China. Int.J.Cancer 2009;124:2942-7

7. Tao, Q. and Chan, A.T.C. Nasopharyngeal carcinoma: molecular pathogenesis and therapeutic developments. Expert Reviews in Molecular Medicine 9.2007 [Cited 2007]. Available from:http//www.expertreviews.org/com

8. Wei, William I, Nasopharyngeal Cancer. In Bailey, Byron, Johnson, Jonas T, Newlands, Shawn D, editors. Head and Neck Surgery Otolaryngology Fourt Edition. Lippincot Williams and Wilkins; 2006.P 1658-68
9. Liu YH, Du CL, Lin CT, Chan CJ, Wang JD. Increased Morbidity from Nasopharyngeal Carcinoma and Chronic Pharyngitis or Sinusitis Among Workers at a Newspaper Printing Company. Occup Rnviron Med 2001;59:18-22

10. Zeng MS, Zeng YX. Pathogenesis and Etiology of Nasopharyngeal Carcinoma. In. Lu J.J, Cooper J.S , Lee A.W.M, editors. Nasopharyngeal Carcinoma. Berlin Heidelberg; 2010. P.9-20

11. Hsu WL, Chen JY, Chien YC, Liu MY, You SL, Hsu MM et al. Independent Effect of EBV and Cigarete Smoking on Nasopharyngeal Carcinoma : A 20 - Year Follow up Study on 9,662 Males without Family History in Taiwan. Cancer Epidemiol Biomarkers Prev 2009;18(4):1218-26

12. Hsu WL, Yu KJ, Chien YC, Chiang CJ, Cheng YJ, Chen JY et al. Familial Tendency and Risk of nasopharyngeal Carcinoma in Taiwan : Effects of Covariates on Risk. American Journal of Epidemiology 2010;10:2-8

13. C.Gaétan,C-Marie,A.G. Desrosiers. Cancer risk assessment for workers exposed to nitrosamines in a warehouse of finished rubber products in the Eastern Townships. (Québec public health institute). Canada.June 2011.

14. Jia WH, Luo XY, Feng BJ, Ruan HL, Bei JX, Liu WS et al. Traditional Cantonese Diet and Nasopharyngeal Carcinoma Risk: a Large Scale Case - Control Study in Guangdong, China. Jia et al.BMC Cancer 2010;10:2-7

15. Hauptmann M, Lubin JH, Stewart PA, Hayes RB, Blair A. Mortality from Solid Cancers among Workers in Formaldehyde industries. Am J Epidemiol 2004;159:1117-30

16. Pinkerton LE, Hein MJ, Stayner LT. Mortality among a cohort of garment workers exposed to formaldehyde: an update. Occup Environ Med 2004;61:193-200

17. Armstrong RW, Imrey PB, Lye MS, Armstrong MJ, Yu MC, Sani S. Nasopharyngeal carcinoma in Malaysian Chinese: Occupational exposures to particles, formaldehyde and heat. International Journal of Epidemiology 2000;29:991-8

18. Marsh GM, Youk AO, Buchanich JM, Erdal S, Esmen NA. Work in the Metal Industry and Nasopharyngeal Cancer Mortality among Formaldehyde Exposed Workers. Regulatory Toxicology and Pharmacology 2007;48:308-19

19. Bosetti C, McLaughin JK, Tarone RE, Pira E, La Vecchia C. Formaldehyde and cancer risk : a quantitative review of cohort studies throught 2006. Annals of Oncology 2008;19:29-43

20. Laantri $N$, Corbex $M$, dardari $R$, Benider $A$, gueddari $B$, Khyatti M.Environmental, genetic and 
viral risk factors of nasopharyngeal carcinoma in North Africa. BMC proceedings 2011;5:1-2

21. Yang X, Diehl S, Pfeiffer R, Chen CJ, Hsu WL, dosemeci $\mathrm{M}$ et al. Evaluation of Risk Factors for Nasopharyngeal Carcinoma in High-Risk Nasopharyngeal Carcinoma Families in Taiwan. Cancer Epidemiol Biomarkers Prev 2005;14: 900-5

22. Chen L, Gallichio L, Lindsley KB, Tao $\mathrm{X}$, Robinson KA, Lam TK et al.Alcohol consumption and the Risk of Nasopharyngeal Carcinoma : A Systematic review.Nutr Cancer 2009;61(1):1-15 
Jurnal Kesehatan Andalas Saat ini sudah diindeks oleh Directory of Open Access Journal (DOAJ)

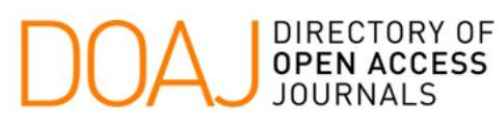

\section{Jurnal Kesehatan Andalas} Andalas Journal of Health 2301-7406 (Print)

\section{(cc) BY-SA}

A

